\title{
Earthquake and Local Rainfall Triggered Giant Landslides in the Unconsolidated Sediment Distribution Region along the Upper Yellow River-Remote Sense Analysis of Geological Disasters
}

\section{Xiaoguang Qin ${ }^{1 *}$ and Zhiqiang Yin ${ }^{2}$}

${ }^{1}$ Institute of Geology and Geophysics, Chinese Academy of Sciences, Beijing 100029, China

${ }^{2}$ China Institute of Geo-environment Monitoring, Beijing 100081, China

\section{The Surrounding Area of the Tibetan Plateau is a Geological Disaster-Prone Region}

All over the world, in mountains with huge altitude difference and intense rainfall, landslides and debris flows frequently take place and are the major geological hazards [1-5], such as in the surrounding areas of the Tibetan Plateau. The Upper Yellow River, that locates in the northern part of the Tibetan Plateau and consists of four basins areas (i.e., Guide, Jianzha, Xunhua and Guanting) from Longyangxia Gorge to Shigouxia Gorge, is such a geological disaster-prone area (Figure 1). In the region, the altitude difference of many mountain slopes is larger than $1000 \mathrm{~m}$. Landslides and debris and mud flows develop widely in the region. At least 450 landslides have been identified from remotely sensed images.

\section{The Enormous Scale of Landslides in the Region is Rare in the World}

Several landslides developed along the banks of the Yellow River. For example, the Xiazangtan landslide that occurred on the south bank of the Yellow River affected an area of $\sim 5.6 \mathrm{~km} \times \sim 3.8 \mathrm{~km}$ and mobilized a volume of $15.05 \times 10^{8} \mathrm{~m}^{3}$. It directly impacted four villages and was reported as the largest one to occur in China [6,7] (Figure 2). In its front edge, there are two sub-scale landslides that occurred later. On the top of the landslide body, on its southern side, there was an ancient lake that had disappeared before the Holocene [6] because a deep ditch had cut throughout the landslide body from south to north at the west
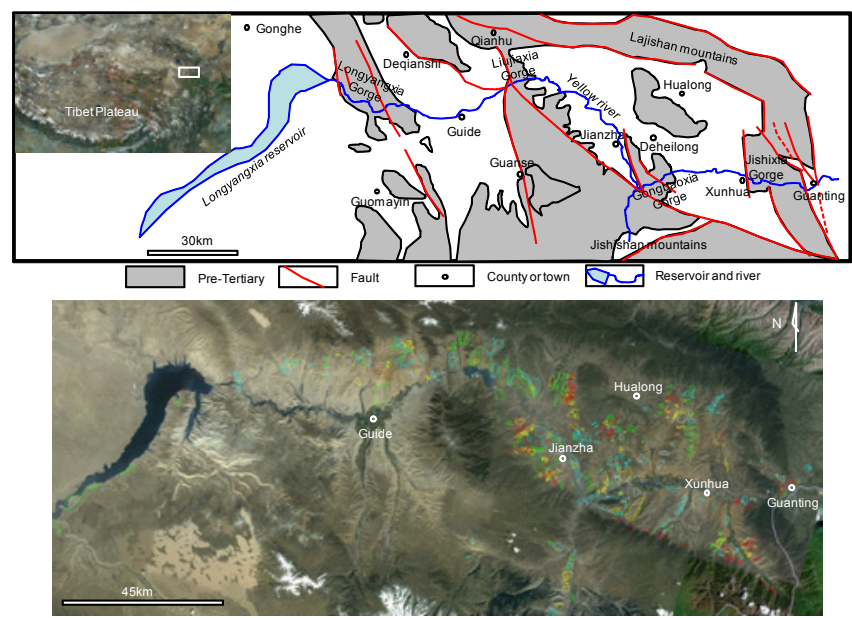

Figure 1: Location of studied area (a) Location of the studied area on the Tibetan Plateau (b) Frame map of structures (c) Distribution map of landslides (possible order: cyan line>green line>yellow line) and fractures (red line) interpreted from remotely sensed images. Blue uppercase Letters are locations of figures: A-Figure 2-3, B-Figure 4, C-Figure 5, D1,2,3-Figure 6a,b,c, E1,2-Figure7a,b, F-Figure8, G-Figure 9, H-Figure 10, I-Figure 11 (All remotely sensed images come from GoogleEarth). section of its trailing edge. In recent years, irrigation water accelerated the development of the ditch (Figure 3).

However, another giant landslide with dimension of $\sim 5.6 \mathrm{~km} \times \sim 8.5$ $\mathrm{km}$ was found on the south bank of the Gongbaoxia Gorge from remotely sensed images and according to its surrounding topography. A southnorth wide valley suddenly narrows due to the impact of the landslidelike mountain showing abnormal terrain features. A low ridge at the southeast side of the landslide-like mountain has remained between the south-north wide valley and an east-west gully with a slip surface-like slope that locates at the south of the landslide-like mountain, implying that there should be a big mountain at the position of the east-west gully. We named this landslide-like mountain the Xiuricun landslide. It may be truly the biggest landslide in the world if it can be confirmed by field work (Figure 4).

In some narrow gorges, landslide bodies may block the Yellow River to form dammed lakes. This is the case in the Jishixia gorge where the Gelongbu giant landslide formed a dammed lake along the river in the Xunhua basin [8] (Figure 5). The $\delta^{14} \mathrm{C}$ ages of organic matter from the top and bottom samples of the dammed lake sediment is $9100 \pm$

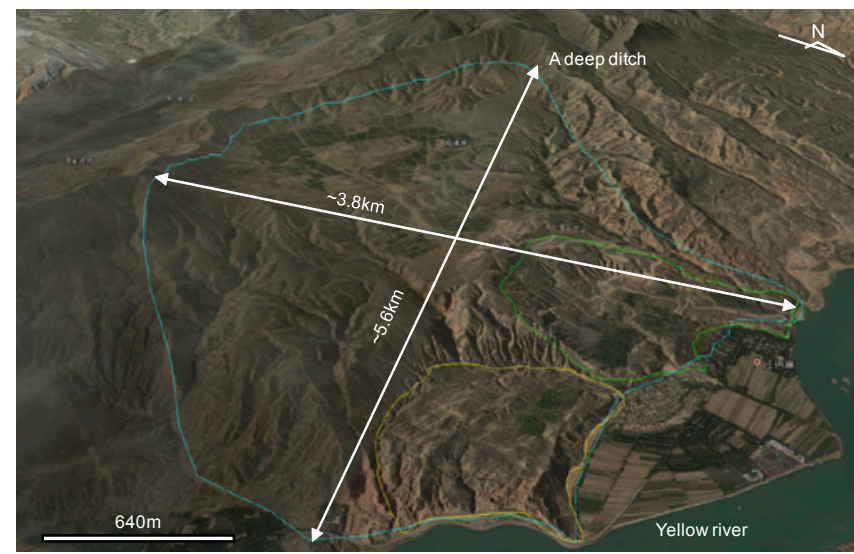

Figure 2: A perspective view of the Xiazangtan landslide on the south bank of the Yellow River.

*Corresponding author: Xiaoguang Qin, Institute of Geology and Geophysics, Chinese Academy of Sciences, Beijing, China, E-mail: xiaoguangqin@mail.iggcas.ac.cn

Received October 10, 2012; Accepted October 15, 2012; Published October 22, 2012

Citation: Qin X, Yin Z (2012) Earthquake and Local Rainfall Triggered Giant Landslides in the Unconsolidated Sediment Distribution Region along the Uppe Yellow River-Remote Sense Analysis of Geological Disasters. J Geophys Remote Sensing 1:e105. doi:10.4172/2169-0049.1000e105

Copyright: (c) 2012 Qin X, et al. This is an open-access article distributed under the terms of the Creative Commons Attribution License, which permits unrestricted use, distribution, and reproduction in any medium, provided the original author and source are credited. 


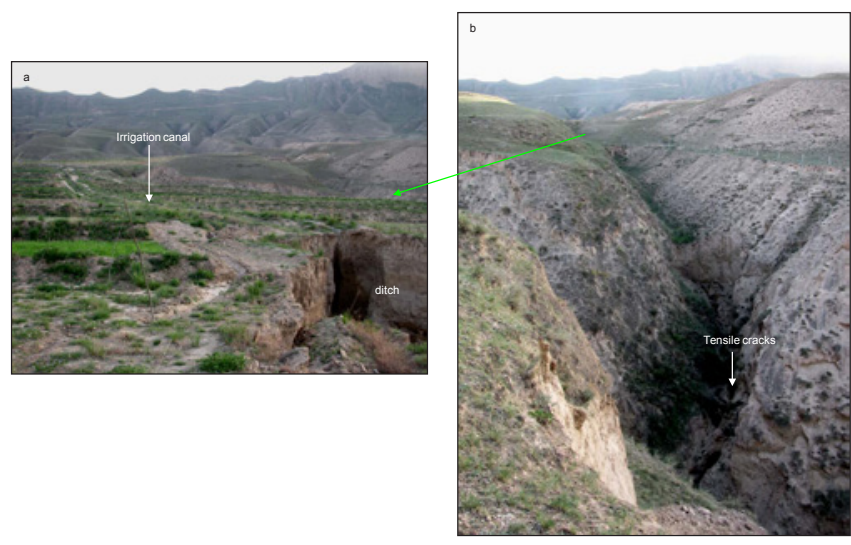

Figure 3: A deep ditch cuts throughout the landslide body from south to north at the western section of its trailing edge. (a) a deep branched ditch rapidly developed at the end of an irrigation canal within one year. (b) the main ditch developed along tensile cracks. Green arrow shows the position of the photo.

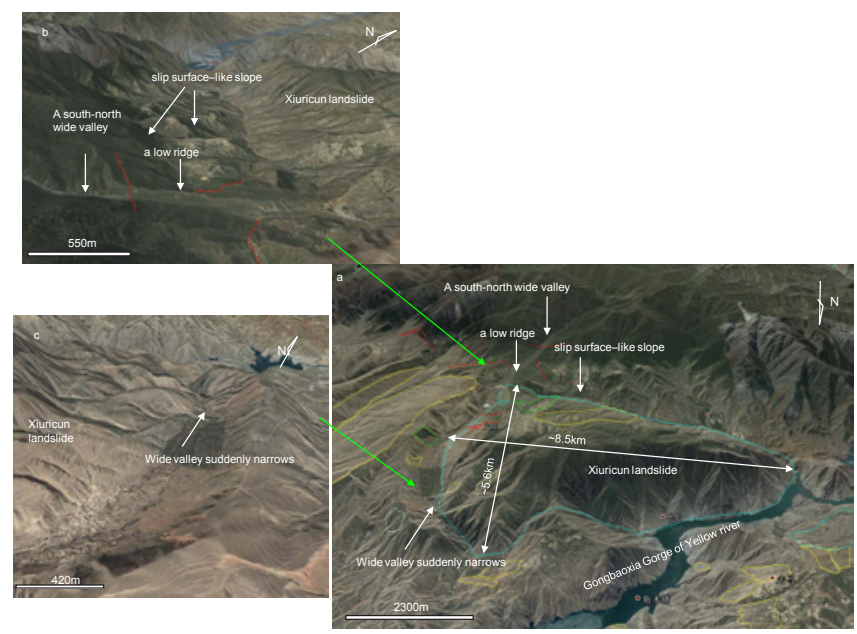

Figure 4: Perspective views of the Xiuricun landslide-like mountain on remotely sensed images. (a) a macro-view of the landslide-like mountain (b) a perspective view of slip-like surface from east to west (c) a perspective view of narrowed wide valley from south to west. Green arrows show the position of the images. Closed lines of different colors are landslides interpreted on remotely sensed images. Red lines are extensional fractures identified on images.

40yrBP (cal) and $10590 \pm 50 \mathrm{yrBP}(\mathrm{cal})$ respectively (measured by Beta Laboratory, USA). These ages imply that the dammed lake was formed in a short time and had outburst in the early Holocene.

\section{The Unconsolidated Sediments of Tertiary, Quaternary and Cretaceous Sandstones are Major Materials of Landslides}

Quaternary sediments consist of two types: fluviolacustrine deposits and eolian loess deposits. The first mainly distribute in valleys and the second usually distribute on the slopes of mountains. In some areas, loess older than the last glacial period (LG) occurred on fluvial terraces. However, loess that covers most areas is composed of eolian deposits from the LG and the Holocene. Tertiary red clay and sand sediments are semi-consolidated depositions that are distributed widely in the upper Yellow River and constitute most of the mountains in the region (Figure 6). Because of the unconsolidated property of Tertiary and Quaternary sediments, landslides easily developed in mountains formed with these sediments. The Xiazangtang landslide body consists of Tertiary red clay and sand sediments.

Cretaceous sediments mainly consist of purple red sandstones and are distributed in several gorges of the Yellow River. The Gelongbu landslide body developed on Cretaceous sediments. Most landslide bodies in the region are developed from Quaternary loess, Tertiary semi-consolidated red clay and sandy sediments, or Cretaceous purple red sandstones. Landslides that developed from Cretaceous sediments are obviously less common than those from Tertiary and Quaternary sediment regions. Although there are Triassic and Carboniferous sediments in the south of the region, these are more affected by collapses than landslides.

Summarizing the landslide patterns on different sediments will be helpful to reveal the development rules of landslides in the region.

\section{The Upstream Region Of The Yellow River Represents An Archive Of Landslide Patterns}

Landslide patterns are very diverse in the region. The Xiazangtan landslide is a good example of the standard landslide morphology. The shape of landslide can be triangular, inverted triangular, or rectangular. In some cases, several landslides developed on a slope and formed several step-like patterns (Figure 7a). In other cases, several landslides
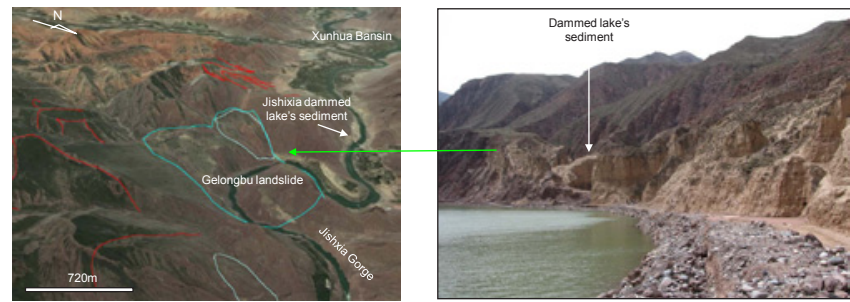

Figure 5: The Gelongbu landslide located at the entry of Jishixia Gorge and dammed lake. (a) a perspective view of landslide damming body (b) the field photo of dammed lake's earth yellow-colored clay and sand sediment. Green arrow shows the position of the photo. Closed lines of different colors are landslides interpreted on remotely sensed images. Red lines are extensional fractures identified on images.
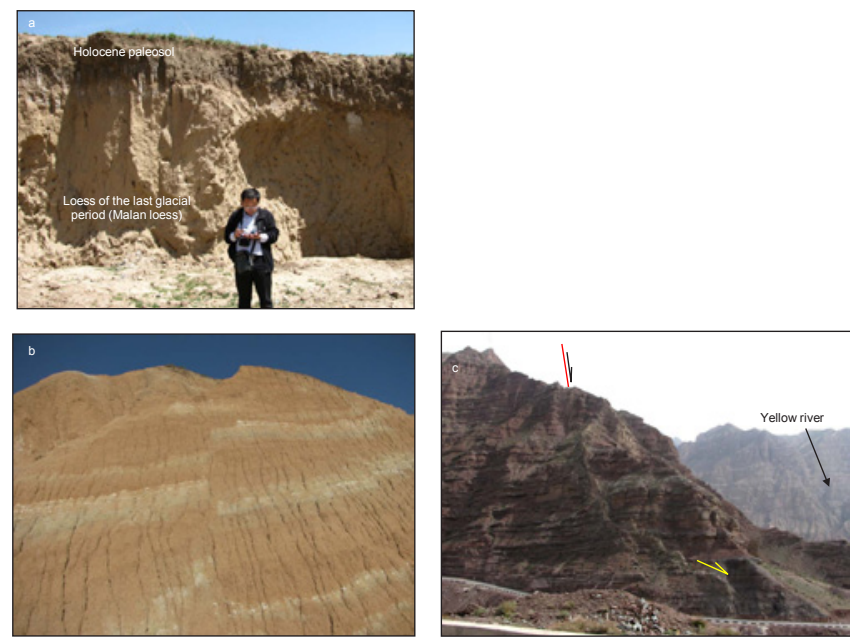

Figure 6: Sediments of Quaternary, Tertiary and Cretaceous (a) Eolian sediment of late Quaternary in north of Guanting basin (b) Tertiary semi-consolidated sediments in Xunhua basin (c) Cretaceous sandstone and the slip surface of a potential landslide in Jishixia Gorge. 
Citation: Qin X, Yin Z (2012) Earthquake and Local Rainfall Triggered Giant Landslides in the Unconsolidated Sediment Distribution Region along the Upper Yellow River-Remote Sense Analysis of Geological Disasters. J Geophys Remote Sensing 1:e105. doi:10.4172/2169-0049.1000e105

Page 3 of 5
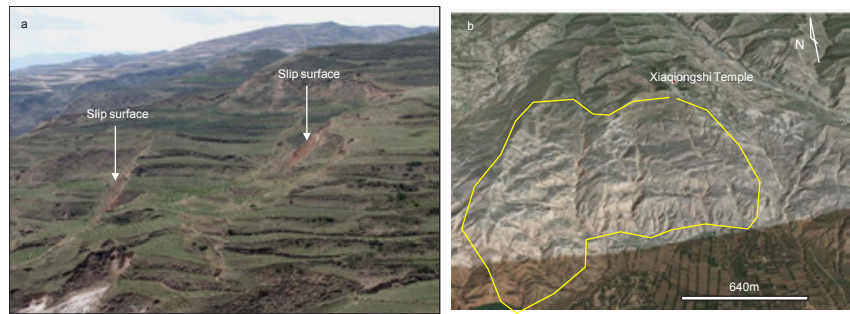

Figure 7: Landslide's landforms (a) several landslides developed on a slope like several steps in Yangjiaocun (b) the Xiaqiongsi landslide developed like a fold dough.
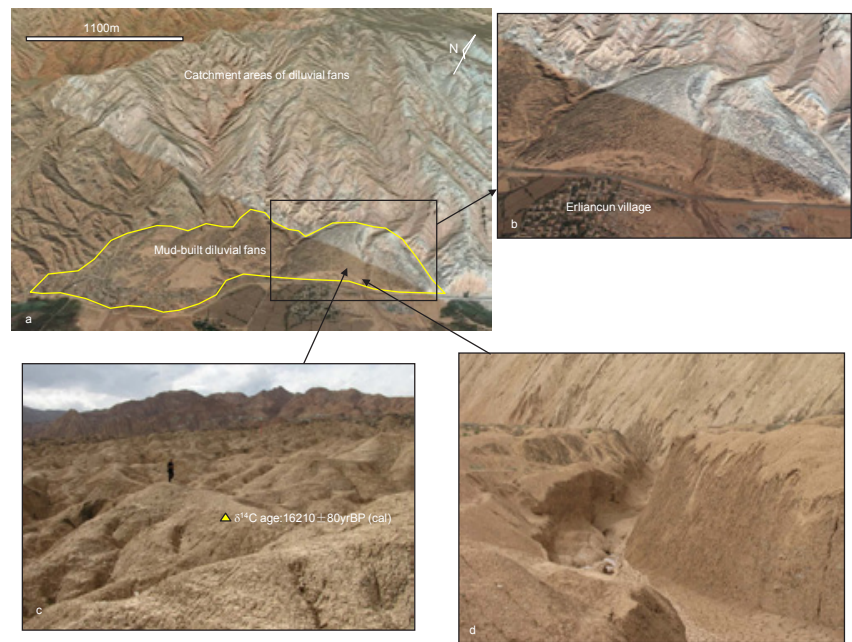

Figure 8: Diluvial fan formed by mud flow in Guide basin.

(a) A perspective view of mud flow-formed diluvial fan (b) zoomed-in on the mud flow-formed diluvial fan (c) the rugged diluvial fan's surface without vegetation cover (d) a ditch of mud passes through the diluvial fan.

developed as a row on a slope. Some giant landslides that consist of unconsolidated sediments and developed on a gentle slope, such as the Xiaqiongsi landslide, may slip only a short distance to leave a scarp behind there body. In that case the surface of the landslide body resembles fold dough, (Figure $7 \mathrm{~b}$ ).

In addition, mud flows represent another geological process that causes economically important hazards as they seriously affect road traffic. In the Guide basin, mud flows formed a special diluvial fan characterized by a rugged surface without any vegetation and a lot of deep pits (Figure 8). In fact, mud flows are a kind of debris flow. Their debris materials come from Tertiary semi-consolidated fine sediments which grain size is less than $10 \mu \mathrm{m}$ and indicates a deep lake sedimentary environment. This fine grain-built debris is easily broken as mud. The $\delta^{14} \mathrm{C}$ age of organic matter in a sample from the diluvial fan was found to be $16,210 \pm 80 \mathrm{yrs} \mathrm{BP}$ (cal), indicating that the mud flow took place due to a rapid increase of melt water caused by warming in the last deglacial period. In that period, relatively low temperature limited the growth of vegetation. However, it is still not known how deep pits developed on the surface of the mud-built fan.

\section{Large Human Populations can Potentially be Affected by Landslides in the Region}

With an average annual rainfall of only about $300 \mathrm{~mm}$, the semidry climate that characterizes this region can only support poorly developed vegetation with low cover, particularly on mountains of Tertiary sediments due to the poor water-holding capacity of these unconsolidated sediments. While most people live in valleys and basins, parts of the people live on the loess-covered slopes. Some villages directly locate on a landslide body and some villages are near the leading edge of landslide bodies. Thus, landslides seriously threaten the

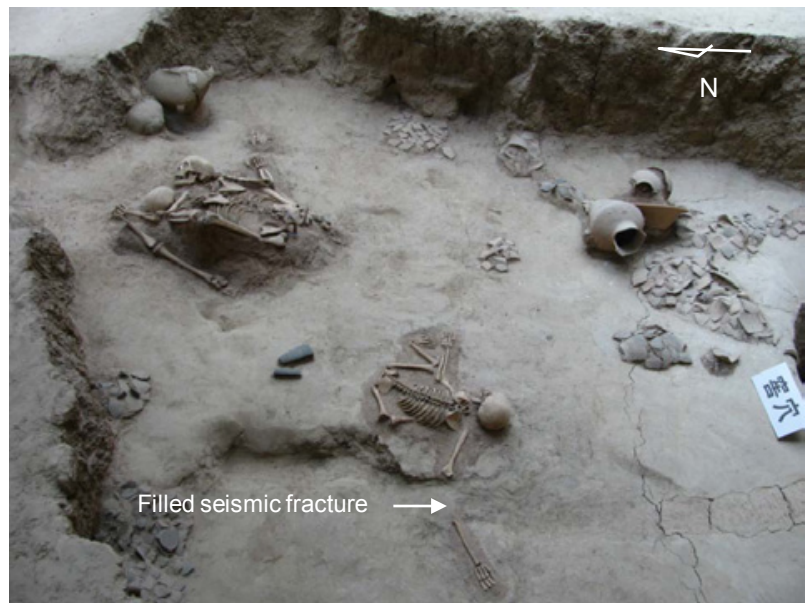

Figure 9: Remains of a mother and her children in Lajia ruin destroyed by a ancient earthquake.
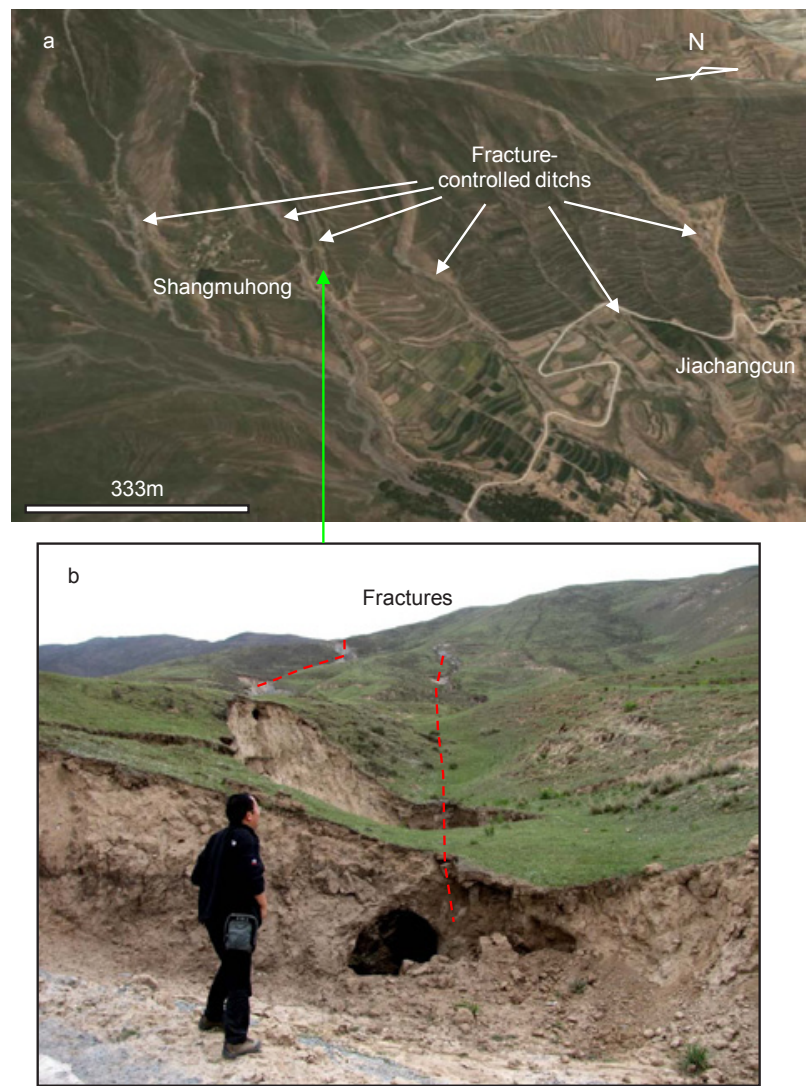

Figure 10: Ditches caused by extensional fractures on the mountain ridge of Jiachangcun village (a) a perspective view of fracture-controlled ditches on remotely sensed image (b) a field photo of extensional fractures that led to the formation of ditches. 
habitations and livelihood of these people. It is therefore very important to investigate in detail the landslide distribution in the region in order to reduce the risk of disaster for these populations.

\section{Earthquake and Thrust Fault are Important Affecting Factors of Landslide Distribution}

In the region north of Tibetan plateau, the Xiqinling-Jishishan fault belt and the Lajishan fault belt that extend hundreds of kilometers, are the two active and important thrust fault belts [7]. Modern earthquake records show that several earthquakes occurred along the Lajiashan fault.

Archaeological studies showed that villages were destroyed by earthquakes in the past. An example is the $\sim 4000$ yrs BP Lajia ruins that are located in the Guanting basin on the east side of the Lajishan fault $[9,10]$. The oldest millet-based noodle in the world was discovered in the ruins of this village [11]. The ancient loess cave-village was destroyed by a sudden earthquake as testified by the many remains found on the site (Figure 9). The strike of the seismic fracture in the ruins is about NW $345^{\circ}$, close to the Lajishan fault. Because remains in the ruins were covered by a layer of red clay, it was assumed that the flood caused by the outburst of the Jishixia dammed lake (Figure 5) submerged the Lajia ruins and deposited the red clay layer after the ancient village was destroyed by an earthquake [12]. However, our recent studies show that the outburst of the dammed lake occurred before the village was destroyed and that the red clay layer came from landslide bodies on mountains in the north of the ruins and not from the upper Yellow River. The exact location of the epicenter of this earthquake and the identity of the fault that caused it remain unknown.

In most mountain ridges, many white belts were identified from the perspective view of remotely sensed images. Field investigation in Jiachangcun village of Baizhuang town, Xunhua demonstrates that the features seen on the satellite images are extensional normal fractures $\sim 20 \mathrm{~m}$ wide. These fractures caused the development of deep ditches (Figure 10). These fracture-led ditches and the water-eroded ditches that are also observed on remotely sensed images can be differentiated by the fact that the fracture-led ditches may not extend along the hillside and lack vegetation cover due to their poor water-holding capacity. It was noticed that the profile shape of these fractures is not a simple arc but a complex spade. This strongly suggests that any attempt to simulate landslides in this region must consider these complicated features of slip-surface.

\section{Distribution of extensional fractures}

South of the Yellow River, most extensional fractures are distributed along the north side of the Xiqinling-Jishishan thrust fault belt and only some fractures occurred along the Jishishan fault belt. Thus, these the development of these fractures should be related to the activity of the two trust fault belts.

North of the Yellow River, intense fractures are mainly distributed around two centers which are located in the Yanglongcun and Xiangjialingcun areas. Many ditches developed along these fractures with extensional property and thus the strike of these ditches on a slope often crosses the slope aspect. Some of them directly became landslides that slipped southward. The huge scale of gravity gliding tectonics North of the Yellow River suggests that some of them cannot be considered as landslide (Figure 11).

\section{Activity property of extensional fractures}

An obvious feature of these fracture-controlled landslides is that

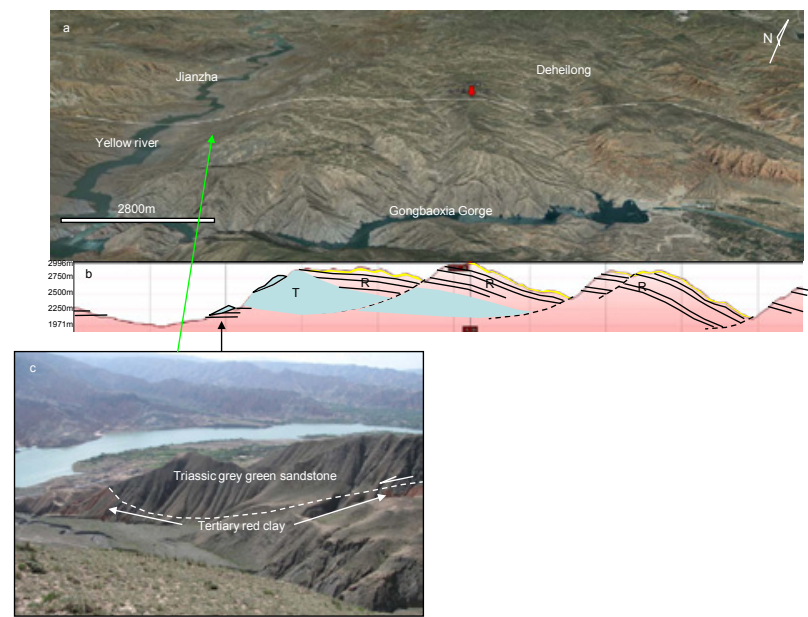

Figure 11: Gravitation-led slipped structures on surface

(a) a perspective view of the region north of Jianzha. The white line is the location of structure profile.

(b) simplified structure profile. yellow layers: loess, red layers: Tertiary red sediments, grey layers: Triassic sediments.

(c) a photo of a landslide body of Triassic grey-green sandstone over Tertiary red clay.

their landslide body slipped toward the Yellow River where the altitude is the lowest in the whole region, i.e., landslides South of the Yellow River slipped northward and vice versa (Figure 11).

The facts that: (1) the fractures South of the Yellow River may be related to the activity of two trust fault belts and (2) the scale of gravity glide faults North of the Yellow River was so large, indicate that earthquake activity along these two thrust faults may be the major triggering force of these extensional fractures. It means that these fracture-led landslides are gravity gliding tectonics that were indirectly generated by regional tectonic stress. However, where the center of each paleo-earthquake was located, when each paleo-earthquake took place, which landslides and fractures were generated by each earthquake are still unsolved issues.

In fact, not all thrust fault-caused features can be interpreted from remotely sensed images. This is because it is difficult to identify thrust faults on remotely sensed images due to their extrusion property that restrained the development of ditches. Thus, more field investigations are necessary to study these earthquake-generated fractures and landslides.

\section{Water is Important for the Development of some Landslides}

Water comes from local rainfall and melt-water of the Tibetan Plateau. Although the average annual rainfall of this region is only about $300 \mathrm{~mm}$, landslides easily develop on unconsolidated sedimentbuilt slopes, such as the Xiazangtang and Xiaqiongshi landslides.

However, the development of the Yellow River deep valley that caused the development of large-scale gravity gliding tectonics is due to the strong erosion caused by large amount of melt-water from the Tibetan Plateau. Local rainfall cannot have caused such erosion because the eolian deposition on slopes implied that rainfall in the region has been very low at least since the last glacial period. The generation of melt-water is related to the increase of temperature or rainfall on the Tibetan Plateau. Thus, it means that past climatic change in the Tibetan 
Plateau and the region may be a key factor to explain the development of landslides in the region.

Former studies showed that landslides in the region usually developed during wet periods over the last 130,000 years, such as the Holocene Optimum and the Marine oxygen isotopic stage 3 (Yin et al.) [6]. However, because changes of rainfall and temperature may generate different effects on the development of landslides, it will be important to reveal the sequences of climate change, in the region, particularly rainfall and temperature.

On the other hand, rainfall-driven and earthquake-led landslides should be distinguished although it is a difficult goal to achieve from remote sensing images. Due to the lubricating effect of water, rainfallcaused landslides usually have smoothed slip planes and fold doughlike ground surfaces.

To summarize the above analysis, the dynamic mechanism for the development of giant landslides in the region is associated with: (1) the uplift of the Tibetan Plateau and the increase of melt-water leading to the strengthening of river erosion that in turn caused the increase of altitude difference along the two banks of the Yellow River; (2) earthquakes caused by the activity of thrust faults and (3) the increase of local rainfall. It is clear that more evidences are necessary to verify the mechanisms involved and to describe them in more details.

This review shows that the powerful perspective view provided by Google Earth is a very useful tool for the identification and analysis of landslides.. However, Google Earth cannot help us to monitor in real-time the development of geological disasters, especially landslides and debris flows. It also cannot inform us on the newest changes of terrain. Early warning and forecasting of geological disasters could only be achieved with real-time stereo images of the region. Such images however, would require a pair of satellites with the same bands but different flight positions. We wish that such satellite technique can be developed as soon as possible.

This study was supported by projects (41172158, 40472094, 40024202) of the National Natural Science Foundation of China, Investigation and Evaluation projects (1212011220123) of Geological and Mineral resources of China Geological Survey, the 973 Program
(2010CB950200) of the National Basic Research Program of China, the CAS Strategic Priority Research Program (grant no. XDA05120502) and the Knowledge Innovation Program of the Chinese Academy of Sciences (KZCX2-YW-Q1-03).

\section{References}

1. Stephen G Evans, Nicholas J Roberts, Anatoli Ischuk, Keith B Delaney, Galina S Morozova et al. (2009) Landslides triggered by the 1949 Khait earthquake, Tajikistan, and associated loss of life. Engineering Geology 109: 195- 212.

2. Bijan Khazai, Nicholas Sitar (2004) Evaluation of factors controlling earthquakeinduced landslides caused by Chi-Chi earthquake and comparison with the Northridge and Loma Prieta events. Engineering Geology 71: 79-95.

3. K Onder Cetin, Nihat Isik, Berna Unutmaz (2004) Seismically induced landslide at Degirmendere Nose Izmit Bay during Kocaeli (Izmit)-Turkey earthquake. Soil Dynamics and Earthquake Engineering 24: 185-197.

4. SA Dunning, WA Mitchell, NJ Rosser, DN Petley (2007) The Hattian Bala rock avalanche and associated landslides triggered by the Kashmir Earthquake of 8 October 2005. Engineering Geology 93: 130-144.

5. Oliver Korup, John J Clague, Reginald L Hermanns, Kenneth Hewitt, Alexander L Strome, et al. (2007) Giant landslides, topography, and erosion. Earth and Planetary Science Letters 261: 578-589.

6. Zhiqiang YIN, Guoming CHENG, Guishou HU, WEI Gang, WANG Yunqing (2010) Preliminary study on characteristic and mechanism of super large landslides in the upper Yellow River since late Pleistocene. Journal of Engineering Geology 18: 41-52

7. Xiaolin LI, Xiaohua GUO, Wanghua LI (2011) Mechanism of Giant Landslides from Longyangxia Valley to Liujiaxia Valley along Upper Yellow River. Journal of Engineering Geology 19: 516-529.

8. ZHOU Hongfu, WEI Yuting, NIE Dexin (2009) Formation Mechanism of HighSpeed Gelongbu Landslide And Associated Blockage Of Upper Reach Yellow River. Journal of Engineering Geology 17: 483-488.

9. IA CASS, QPICRA (2002) Excavation on the Lajia Site at Minhe County, in 2000. Archaeology 12: 12-25.

10. Xiaoyan YANG, Zhengkai XIA, Maolin YE (2003) Prehistoric disasters at Lajia Site, Qinghai, China. Chinese Science Bulletin 48: 1877-1881.

11. Houyuan LU, Xiaoyan YANG, Maolin YE, Kam-Biu LIU, Zhengkai et al. (2005) Millet noodles in Late Neolithic China. Nature 437: 967-968.

12. QL WU, PZ ZHANG, HP ZHANG, et al. (2009) A palaeo-earthquake induced damming and bursting of Yellow River and the abnormal flood that destroyed Lajia relic (in Chinese). Sci China Ser D-Earth Sci. 39: 1148-1159. 